\title{
Soluble Frizzled-7 receptor inhibits Wnt signaling and sensitizes hepatocellular carcinoma cells towards doxorubicin
}

\author{
Wei Wei ${ }^{1}$, Mei-Sze Chua ${ }^{1 *}$, Susan Grepper ${ }^{2}$, Samuel K So ${ }^{1}$
}

\begin{abstract}
Background: There are limited therapeutic options for hepatocellular carcinoma (HCC), the most common liver malignancy worldwide. Recent studies have identified the Frizzled-7 receptor (FZD7), important for activation of Wnt-mediated signaling, as a potential therapeutic target for HCC and other cancers.

Methods: We hypothesized that the extracellular domain of FZD7 (sFZD7) would be a clinically more relevant therapeutic modality than previously studied approaches to target FZD7. We expressed and purified sFZD7 from E. coli, and tested its functional activity to interact with Wnt3, its ability to inhibit Wnt3-mediated signaling, and its potential for combinatorial therapy in HCC.

Results: sFZD7 pulled down Wnt3 from Huh7 cells, and decreased $\beta$-catenin/Tcf4 transcriptional activity in HCC cells. In vitro, sFZD7 dose-dependently decreased viability of three HCC cell lines (HepG2, Hep40, and Huh7, all with high FZD7 and Wnt3 mRNA), but had little effect on normal hepatocytes from three donors (all with low level FZD7 and Wnt3 mRNA). When combined with doxorubicin, sFZD7 enhanced the growth inhibitory effects of doxorubicin against HCC cells in vitro, and against Huh7 xenografts in vivo. Reduced expressions of c-Myc, cyclin D1, and survivin were observed in vitro and in vivo. Additionally, sFZD7 altered the levels of phosphorylated AKT and ERK1/2 induced by doxorubicin treatment in vitro, suggesting that several critical pathways are involved in the chemosensitizing effect of sFZD7.
\end{abstract}

Conclusions: We propose that sFZD7 is a feasible therapeutic agent with specific activity, which can potentially be combined with other chemotherapeutic agents for the improved management of HCC.

\section{Background}

The Wnt/ $\beta$-catenin signaling pathway is commonly dysregulated in various cancers, including hepatocellular carcinoma (HCC) [1]. Aberrations in this pathway have been established to be critical contributors towards hepatocarcinogenesis [2]. In 18-67\% of HCC tumors, activation of this cascade, and subsequent accumulation of nuclear and cellular $\beta$-catenin has been observed $[3,4]$. However, mutations of $\beta$-catenin are detected only in $20-30 \%$ of HCC [3-7]; and loss-of-function mutation of negative regulators axin1 and axin2 are rare in HCC [8-10]. These observations suggest that other upstream elements may be important in the activation of

\footnotetext{
* Correspondence: mchua@stanford.edu

'Asian Liver Center, Department of Surgery, 1201 Welch Road, Stanford

University School of Medicine, Stanford, CA 94305, USA

Full list of author information is available at the end of the article
}

canonical Wnt/ $\beta$-catenin during hepatocarcinogenesis, such as promoter methylation of secreted frizzled-related protein (SFRP) members [11], and over-expression of frizzled (FZD) receptors [12-14].

FZDs are frequently upregulated in tumor cell lines and tissues [1]. All ten members of the FZD family have a highly conserved $\mathrm{N}$-terminal extracellular, cysteine-rich domain for Wnt ligand binding, a seven-transmembrane linker domain, and a C-terminal cytoplasmic domain that is essential for receptor signaling [15]. In HCC, FZD7 was shown to be markedly upregulated in four transgenic mouse models of HCC [16], and in human tumors [12,13]. The over-expression of FZD7 in surrounding peritumoral and dysplastic liver tissues suggested its involvement in early events in hepatocarcinogenesis $[13,16]$. Specifically, functional interaction between FZD7 and the Wnt3 ligand, leading to increased nuclear $\beta$-catenin accumulation, has

\section{C) Biomed Central}


been demonstrated in hepatitis B virus-induced HCC cells [12].

The extracellular domain of FZD receptors serves as binding sites for Wnt ligands (most Wnt ligands will bind to multiple FZDs and vice versa). This interaction is indispensable for the activation of $\mathrm{Wnt} / \beta$-catenin signaling, and interference with this interaction offers a feasible approach to modulate $\mathrm{Wnt} / \beta$-catenin activation in cancers. SFRPs, encoding only the extracellular domain of FZD, act as natural antagonists of the Wnt/ $\beta$-catenin pathway by binding to Wnt ligands and inhibiting their interactions with FZDs [17]. Recent studies have shown that the expression of some SFRP proteins are inhibited in HCC tissues due to promoter methylation [14], and that the restoration of SFRP1 could inhibit $\mathrm{HCC}$ cell growth by blocking the $\mathrm{Wnt} / \beta$-catenin pathway [11]. Additionally, artificial transfection of a plasmid expressing the FZD extracellular domain antagonizes canonical Wnt $/ \beta$-catenin signaling [18] and even induces morphological change and attenuates tumor growth in colon cancer cell lines [19]. More recently, Ueno et al. demonstrated that siRNA against FZD7 could decrease survival, invasion, and metastatic capability of colon cancer cells [20].

Our study investigates a more readily translatable method to interfere with FZD7/Wnt3 interaction, by using the extracellular peptide of FZD7 (named soluble FZD7 or sFZD7) expressed and purified from E. coli to inhibit Wnt/ $\beta$-catenin-mediated signaling in human HCC cell lines. The sFZD7 peptide selectively decreased viability of HCC cells, but not of normal hepatocytes. Additionally, it inhibited downstream $\beta$-catenin/Tcf4 interaction and transcriptional activity regardless of $\beta$-catenin status (wild-type or mutant). In vitro and in vivo, sFZD7 enhanced the growth inhibitory effects of doxorubicin, possibly via down-regulation of target genes of $\mathrm{Wnt} / \beta$-catenin signaling (c-Myc, cyclin D1, and survivin), and also via modulation of the AKT and ERK pathways. Our data suggest that the sFZD7 peptide may allow improved clinical management of HCC, especially when used in combination with standard chemotherapeutic agents.

\section{Results}

sFZD7 peptide binds to Wnt3 ligand and suppresses Wnt3-mediated $\beta$-catenin transcriptional activation in Huh7 cells

FZD7 over-expression in HCC implies an activated, FZD7mediated Wnt/ $\beta$-catenin signaling [13]. We hypothesized that an extracellular domain peptide of FZD7 (soluble FZD7, sFZD7) will be able to bind extracellular Wnt ligands, thereby reducing ligand interactions with FZD7 and inhibiting Wnt/ $\beta$-catenin signaling in HCC. Using $\mathrm{E}$. coli, we expressed and purified sFZD7 with an apparent molecular weight of $27 \mathrm{kDa}$ on SDS-PAGE (Figure 1A).
As a first step to test the functional activity of sFZD7, we used the pull-down assay to demonstrate that sFZD7 was able to bind to Wnt3 (a reported ligand of FZD7) in Huh7 cells (Figure 1B). Using the $\beta$-catenin/Tcf4 transcriptional reporter (TOP/FOPFLASH) luciferase assay in Huh7 cells, we observed that Wnt3 increased $\beta$-catenin transcriptional activity, either alone (2-fold, $\mathrm{P}<0.05$ ) or in combination with FZD7 (3-fold, $P<0.001$ ). Treatment with sFZD7 significantly abolished the Wnt3-induced activation of $\beta$ catenin/Tcf4 transcriptional activity (Figure $1 \mathrm{C},{ }^{*} \mathrm{P}<0.05$ ), further confirming that sFZD7 is functionally active.

\section{sFZD7 inhibits Wnt/ $\beta$-catenin transcriptional activity and} suppresses the expression of downstream oncoproteins To determine the ability of sFZD7 to disrupt Wnt/ $\beta$-catenin signaling in HCC cells, we first looked at its effect on nuclear $\beta$-catenin accumulation. Treatment of Huh7 and HepG2 cells with different concentrations of sFZD7 for $48 \mathrm{~h}$ decreased nuclear $\beta$-catenin accumulation in both cell lines, but did not affect cytoplasmic $\beta$-catenin level. In HepG2 cells that harbor both wild type and truncated $\beta$-catenin [21], sFZD7 decreased the level of wild type $\beta$-catenin only, with negligible effect on the truncated $\beta$-catenin level (Figure 2A). Additionally, $48 \mathrm{~h}$ treatment with sFZD7 caused dose-dependent decreases in $\beta$-catenin/Tcf4 transcriptional activities in both Huh7 and HepG2 cells (Figure 2B). Consistently, the endogenous levels of $\beta$-catenin/Tcf4 regulated proteins (c-Myc, cyclin D1, and survivin) were reduced after $48 \mathrm{~h}$ treatment with sFZD7 $(2 \mu \mathrm{g} / \mathrm{ml})$ in Huh7 and HepG2 cells (Figure $2 \mathrm{C}$ ). These three proteins are known to be over-expressed in HCC [22-24], and our results indicate that their expression is regulated by $\mathrm{Wnt} / \beta$-catenin signaling.

\section{sFZD7 decreases viability of hepatoma cells but not normal hepatocytes}

The inhibitory effects of sFZD7 on the growth promoting, Wnt/ $\beta$-catenin signaling in hepatoma cells suggest that sFZD7 might influence cell viability. We observed that sFZD7 dose-dependently decreased viability of three HCC cell lines (with high FZD7 and Wnt3 expression) after $72 \mathrm{~h}$ treatment, but did not affect normal hepatocytes (with low FZD7 and Wnt3 expression) from three donors (Figure 3A). The correlation between the growth inhibitory effect of sFZD7 and cellular FZD7 and Wnt3 mRNA levels (Figure 3B) provide further support that sFZD7 is acting specifically via the FZD7mediated $\mathrm{Wnt} / \beta$-catenin signaling in $\mathrm{HCC}$ cells, and that it exerts preferential activity against HCC cells over-expressing FZD7 and Wnt3.

sFZD7 sensitizes HCC cells to the anti-proliferative effect of doxorubicin in vitro

Since the Wnt/ $\beta$-catenin signaling pathway has been implicated in chemoresistance of cancer cells [25-28], 


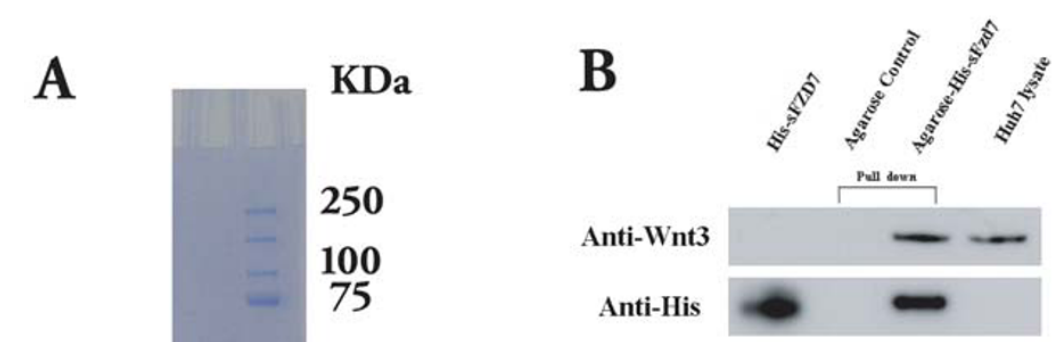

50

37

25

20

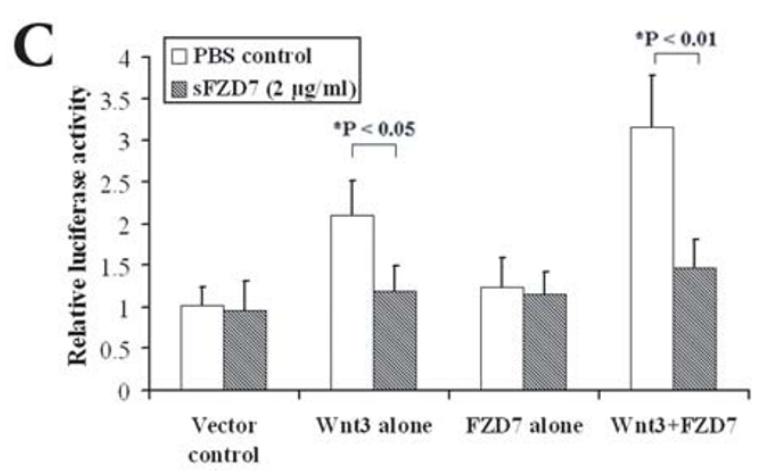

Figure 1 sFZD7 binds to Wnt3 and suppresses Wnt3-induced $\beta$-catenin/Tcf4 transcriptional activation in Huh7 cells. (A). SDS-PAGE analysis of purified SFZD7. (B). Pull-down assay demonstrating the interaction between sFZD7 and Wnt3. Huh7 cells lysate was pulled down with Ni-NTA agarose with or without recombinant His-sFZD7 peptide. Protein complexes were centrifuged and eluted, and the supernatants analyzed by Western blot using rabbit anti-Wnt3 antibody (upper panel) and anti-His antibody (lower panel). Huh7 lysate and recombinant His-sFZD7 were used as positive controls. (C). sFZD7 abolished the Wnt3-induced $\beta$-catenin/Tcf4 transcriptional activity in Huh7 cells. Huh7 cells were transfected with $0.2 \mu \mathrm{g}$ of each of the indicated expression plasmid, along with $0.3 \mu \mathrm{g}$ of pTOPFLASH or pFOPFLASH reporter plasmids and 0.1 $\mu \mathrm{g}$ of $\beta$-gal to normalize for transfection efficiency. The results are expressed as means \pm SD (error bars) of triplicate assays. ${ }^{*} P<0.05$ versus control.

we next tested whether sFZD7 can sensitize hepatoma cells to the standard chemotherapeutic agent doxorubicin. We demonstrate that sFZD7 (at $2 \mu \mathrm{g} / \mathrm{ml}$ ) significantly decreased the $\mathrm{IC}_{50}$ value of doxorubicin in Huh7 cells from $0.10 \pm 0.02 \mu \mathrm{M}$ to $0.05 \pm 0.01 \mu \mathrm{M}, \mathrm{P}<0.05$; and the $\mathrm{IC}_{50}$ value of doxorubicin in HepG2 cells from $7.42 \pm 0.90 \mu \mathrm{M}$ to $4.66 \pm 0.52 \mu \mathrm{M}, \mathrm{P}<0.05$ (Figure $4 \mathrm{~A}$, Table 1). Because doxorubicin itself had negligible effects on the expression of c-Myc, cyclin D1 or survivin, we further detected the activation states of AKT and ERK1/2 in Huh7 and HepG2 cells after treatment with sFZD7 and doxorubicin, since these two pathways are also stimulated by Wnt proteins [29]. In both cell lines, doxorubicin alone induced a significant increase in phospho-AKT level (Figure 4B), which was reduced when sFZD7 was combined with doxorubicin (Figure 4B). Total AKT levels were unchanged. Doxorubicin alone also induced the levels of phospho-ERK1/2; however, when sFZD7 was combined with doxorubicin, phospho-ERK1/2 levels were further enhanced without affecting total ERK levels (Figure 4B). Complex crosstalk among these critical pathways (Wnt, AKT, ERK) may together account for the chemosensitizing effect of sFZD7.

\section{sFZD7 sensitizes HCC cells to the anti-proliferative effect} of doxorubicin in vivo

In vivo, 14-days treatment with sFZD7 only, Doxil only, or sFZD7 combined with Doxil caused significantly delayed tumor growth in Huh7 xenografts in nude mice, 

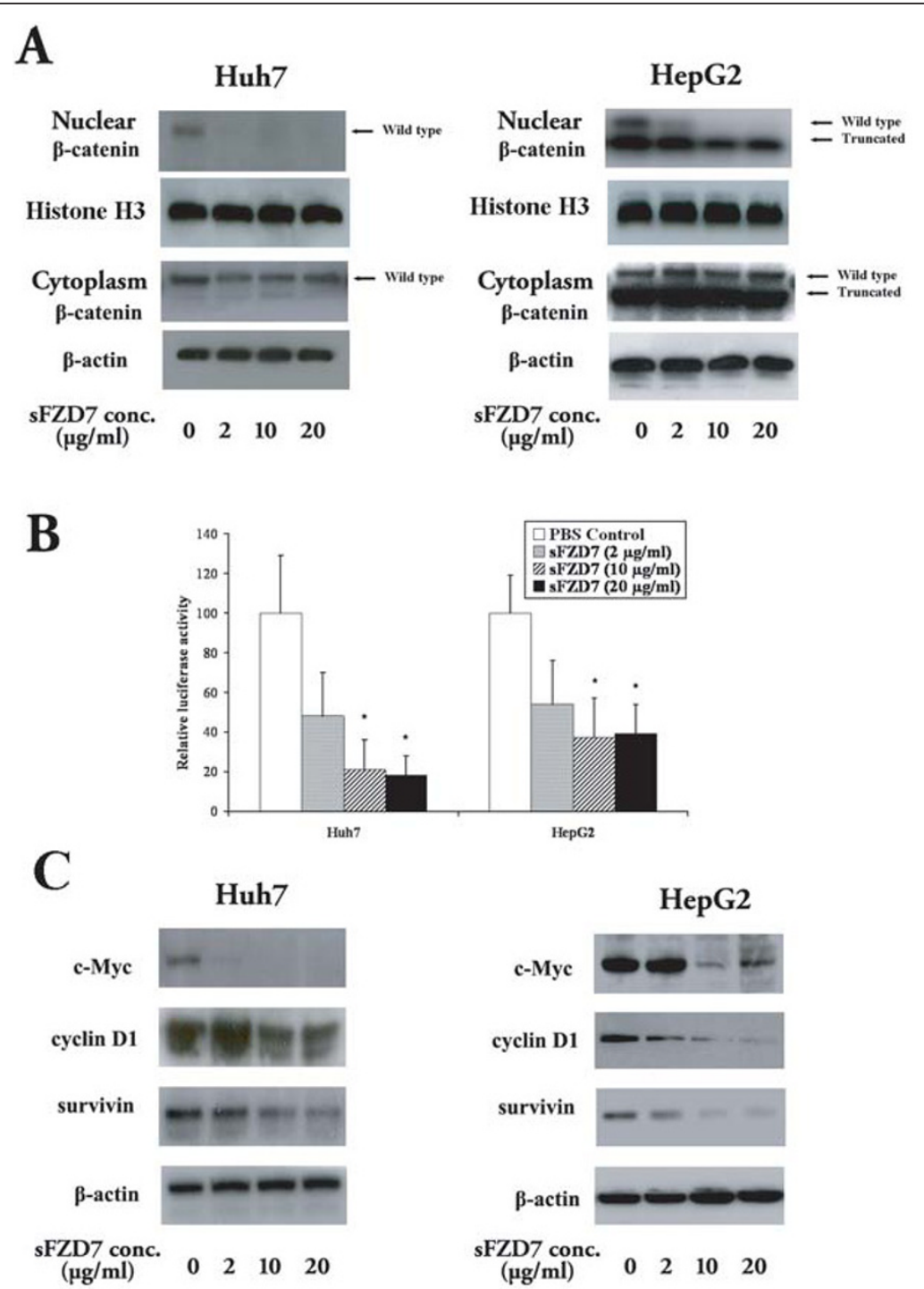

Figure 2 sFZD7 inhibits Wnt/ $\beta$-catenin signaling and suppresses the expression of downstream oncoproteins. (A). sFZD7 decreased nuclear $\beta$-catenin accumulation but did not decrease cytoplasmic $\beta$-catenin in Huh7 and HepG2 cells. Histone-H3 and $\beta$-actin were used as loading controls for nuclear and cytoplasmic proteins, respectively. (B). Tcf4 reporter assay of Tcf4-dependent transcriptional activity in Huh7 and HepG2 cells. Cells were co-transfected with plasmid encoding $\beta$-gal (a control for transfection efficiency) and either the pTOPFLASH or pFOPFLASH reporters. Cells were incubated with control PBS or sFZD7 at various concentrations and harvested after $48 \mathrm{~h}$ to measure luciferase and $\beta$-gal activities. Reporter gene activation is expressed as relative light units (RLU) detected in pTOPFLASH or pFOPFLASH transfected cells and normalized for $\beta$-galactosidase activity. The results are expressed as mean \pm SD (error bars). Experiments were performed in triplicates (Independent t-test, ${ }^{*} P<0.05$.) (C). The effect of sFZD7 on the expression of $\beta$-catenin/Tcf4 target genes c-Myc, cyclin D1, and survivin. Huh7 and HepG2 cells were incubated for $48 \mathrm{~h}$ with sFZD7 at various concentrations and c-Myc, cyclin D1, survivin, and $\beta$-actin (loading control) levels were determined by Western blotting using specific antibodies.

when compared to PBS control (Figure 5A) (independent sample t-test, $\mathrm{P}=0.048$ for sFZD7 only; $\mathrm{P}=0.041$ for Doxil only; $\mathrm{P}=0.001$ for sFZD7 plus Doxil). Additionally, the sFZD7 plus Doxil group showed significantly reduced tumor growth when compared with other treatment groups at day 17 of treatment $(\mathrm{P}=$ 0.041, compared with sFZD7 only; $\mathrm{P}=0.035$, compared with Doxil only).
Tumor xenografts were harvested for TUNEL staining at the end of the treatment period, and apoptotic cells were detected in tumors treated with sFZD7, Doxil, or sFZD7 combined with Doxil (Figure 5B). Whereas the PBS control tumors have less than $10 \%$ apoptotic cells, there were between 10-30\% apoptotic cells in the sFZD7 or Doxil single treated tumors, and more than $50 \%$ apoptotic cells in the sFZD7 and Doxil combined 


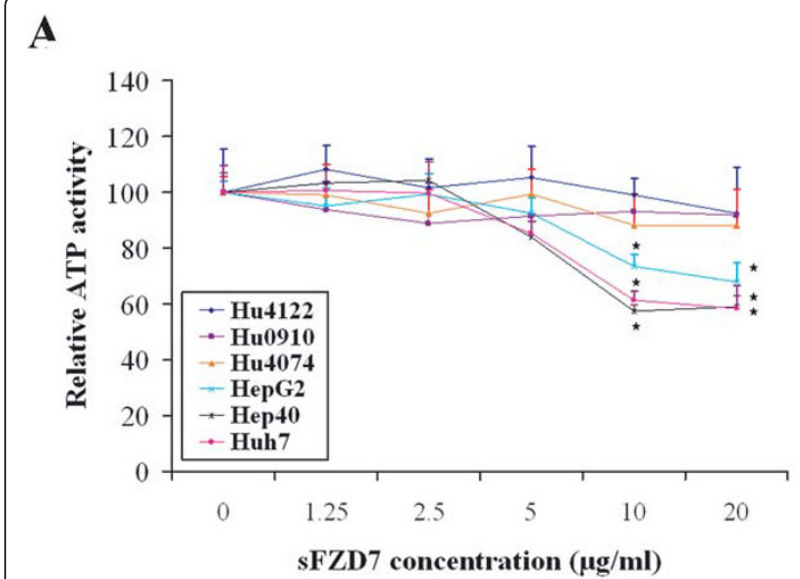

B
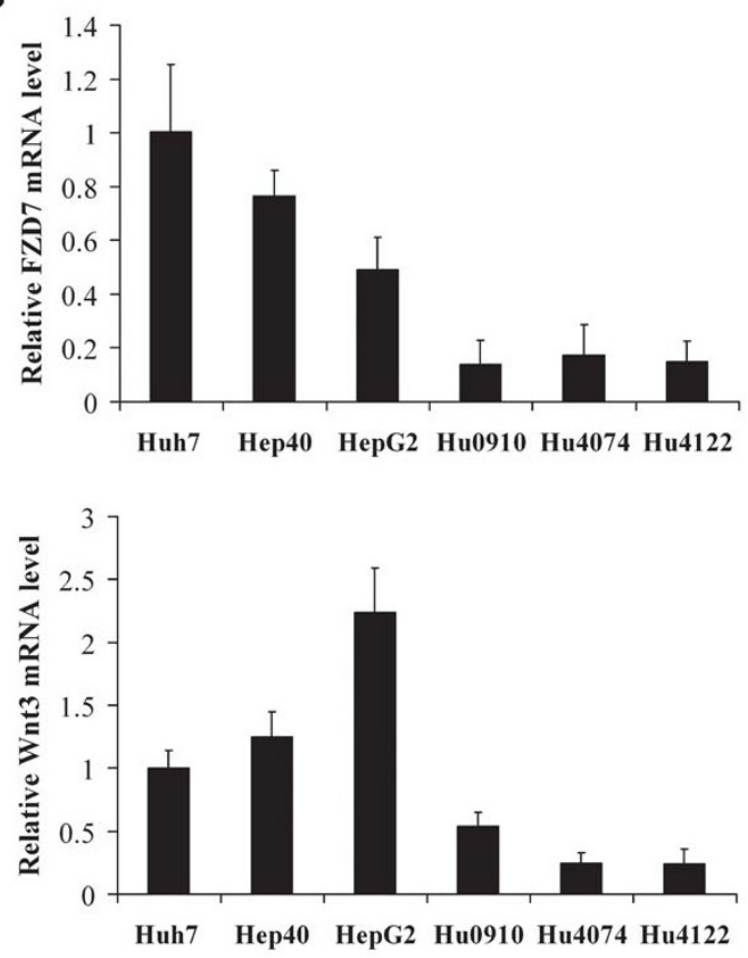

Figure 3 sFZD7 decreases viability of hepatoma cells but not of normal hepatocytes. (A). Cell viability assay based on cellular ATP content was used to determine the in vitro activity of sFZD7 on three human HCC cell lines and normal hepatocytes from three donors following $72 \mathrm{~h}$ of sFZD7 treatment (Independent t test, ${ }^{*} \mathrm{P}<$ 0.05). Three independent experiments were done, each in triplicates, (B). The relative FZD7 and Wnt3 mRNA levels were detected in HCC cell lines and normal hepatocytes from three donors. Data are represented as means \pm SD (error bars) from triplicate experiments.

treated tumors. The expression of c-Myc, cyclin D1, and survivin were visualized by immunostaining and Western blotting (Figure 5C-E). While Doxil itself had negligible effect on the expression of c-Myc, cyclin D1, or survivin, sFZD7 alone or in combination with Doxil decreased the tumor levels of these three downstream target proteins of Wnt/ $\beta$-catenin signaling. This is consistent with our in vitro observations that sFZD7 inhibited $\beta$-catenin/Tcf4 mediated transcriptional activity, which might contribute to the observed tumor growth inhibition by sFZD7, and its chemosensitizing effect with Doxil.

\section{Discussion}

HCC patients typically have a dismal prognosis, especially if they are diagnosed late. The rising incidence of HCC (the fifth most common cancer globally), and the current lack of effective systemic treatment options, makes it imperative to develop novel and efficacious treatment strategies to overcome current challenges, which include intrinsic resistance to standard chemotherapeutic agents. Recent advances in HCC pathology have identified activated signaling pathways as new therapeutic targets [30-32]. The Wnt/ $\beta$-catenin pathway and its many components are especially attractive targets because of their functional importance in hepatocarcinogenesis. Among them, FZD7 has been considered a promising therapeutic target [20,33] because FZD7 mediated Wnt/ $\beta$-catenin signaling is closely associated with growth and survival of tumor cells $[8,34]$. Additionally, elevated FZD7 mRNA levels have been reported in HCC and other cancers [12,13,35-39]. Our study explores the use of a purified, soluble ectodomain peptide of FZD7 (sFZD7, containing the cysteine-rich domain that interacts with Wnt ligands) as a new therapeutic modality for inhibiting FZD7/Wnt-mediated signaling in $\mathrm{HCC}$.

We first confirmed the functional activity of sFZD7 by demonstrating its ability to bind to its known ligand, Wnt3, using a pull-down assay in Huh7 cells. Additionally, sFZD7 blocked Wnt3-induced $\beta$-catenin/Tcf4 transcriptional activation in Huh7 cells, confirming its functional activity. In Huh7 and HepG2 cells, sFZD7 caused dose-dependent inhibitions of nuclear $\beta$-catenin accumulation and $\beta$-catenin/Tcf4 transcriptional activity, together with reduced expressions of downstream target genes c-Myc, cyclin D1, and survivin. These effects of sFZD7 might underlie its growth inhibitory effects against three hepatoma cell lines (with high expression of FZD7 and Wnt3 mRNA), but not against normal primary hepatocytes (with low expression of FZD7 and Wnt3 mRNA). Our results also suggest that sFZD7 exerts inhibitory effects on Wnt/ $\beta$-catenin signaling and cell growth regardless of $\beta$-catenin status (wild type or mutant). HepG2 cells, which are known to have a constitutively active, truncated mutant of $\beta$-catenin lacking the GSK-3 $\beta$ regulatory site [21], respond similarly to sFZD7 treatment as do Huh7 cells with wild type $\beta$-catenin. Whether the truncated $\beta$-catenin could be 
A

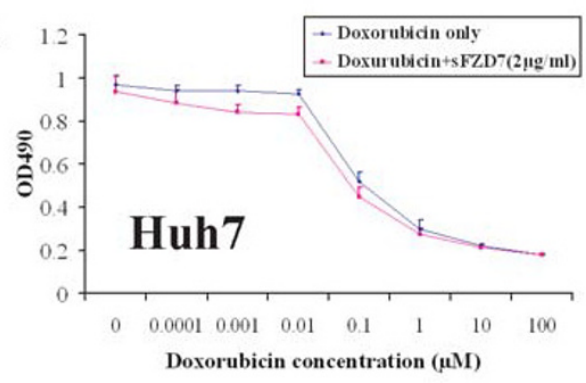

B

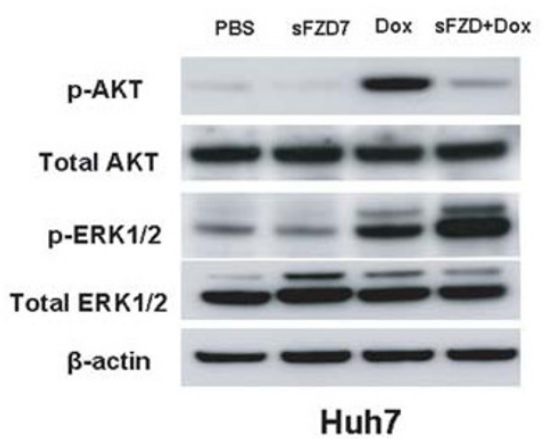

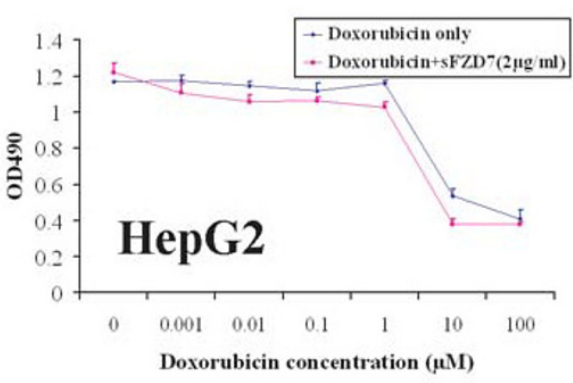

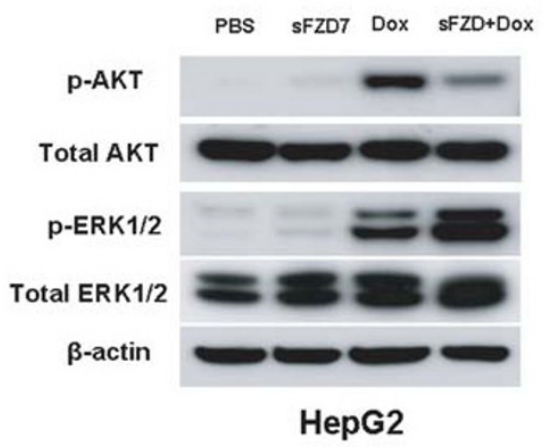

Figure 4 sFZD7 sensitizes HCC cells to doxorubicin treatment in vitro. (A). sFZD7 sensitizes HCC cells to anti-proliferative effect of doxorubicin in vitro. Huh7 and HepG2 were treated with various concentrations of doxorubicin with or without sFZD7 (2 $\mu \mathrm{g} / \mathrm{ml})$ for $72 \mathrm{~h}$, and cell proliferation determined as described under Materials and Methods. Data are means \pm SD (error bars). (B). The effect of sFZD7 on the activation of AKT and ERK1/2 induced by doxorubicin. Huh7 and HepG2 cells were incubated with sFZD7 (10 $\mu \mathrm{g} / \mathrm{ml})$ for $48 \mathrm{~h}$, and then doxorubicin $(2.5 \mu \mathrm{M})$ was added for another $6 \mathrm{~h}$. The phospho-AKT, total AKT, phospho-ERK1/2, total ERK1/2, and $\beta$-actin (loading control) levels were determined by Western blotting using specific antibodies.

regulated by upstream events remains controversial. Shih et al. observed that restoration of SFRP attenuated Wnt signaling in Huh6 cells (with a $\beta$-catenin point mutation), but not in HepG2 cells with truncated $\beta$-catenin [11]. However, our findings are consistent with those of Hocevar et al., who observed that the stable over-expression of Dab2, which stabilizes axin as a binding partner of Dvl-3 and axin, decreased nuclear

Table 1 IC 50 values for doxorubicin with or without sFZD7 in human heptaoma cell lines following $\mathbf{7 2} \mathrm{h}$ of drug treatment in vitro

\begin{tabular}{llll}
\hline $\begin{array}{l}\text { Cell } \\
\text { line }\end{array}$ & $\begin{array}{l}\mathrm{IC}_{50}(\boldsymbol{\mu M}) \\
\text { Doxorubicin only }\end{array}$ & $\begin{array}{l}\mathrm{IC} \boldsymbol{C}_{50}(\boldsymbol{\mu M}) \text { Doxorubicin } \\
+\mathrm{sFZD7}(\mathbf{2} \boldsymbol{\mu g} / \mathbf{m l})\end{array}$ & $\begin{array}{l}\text { Sensitivity } \\
\text { Index }\end{array}$ \\
\hline Huh7 & $0.10 \pm 0.02$ & $0.05 \pm 0.01^{*}$ & 2.00 \\
HepG2 & $7.42 \pm 0.90$ & $4.66 \pm 0.50^{*}$ & 1.59 \\
\hline
\end{tabular}

Values are expressed as mean \pm SD. The chemosensitizing effects of doxorubicin in combination with SFZD7 are expressed as the sensitivity index (Mean $\mathrm{IC}_{50}$ value for doxorubicin alone/Mean $\mathrm{IC}_{50}$ value for doxorubicin + sFZD7). Independent T-test was used to compare the $I_{50}$ values of doxorubicin alone or in combination with sFZD7; ${ }^{*} \mathrm{P}<0.05$ in both cell lines. $\beta$-catenin accumulation and inhibited $\beta$-catenin transcriptional activity in HepG2 cells [40].

In addition to its fundamental roles in tumor cell growth and survival, the Wnt/ $\beta$-catenin signaling pathway is also implicated in the development of chemoresistance in a wide variety of cancer cells [25-28]. Since $\mathrm{HCC}$ is highly chemoresistant and lacks effective therapeutic options [41], we tested the ability of sFZD7 to sensitize HCC cells to treatment with doxorubicin, commonly used for treating HCC. In vitro, sFZD7 sensitized Huh7 and HepG2 cells to the anti-proliferative effects of doxorubicin. In vivo, combined sFZD7 and Doxil treatment significantly augmented the growth inhibitory effects of either sFZD7 alone or Doxil alone on HCC xenografts. This observation may in part be due to the ability of sFZD7 to reduce the expression of survivin, a Wnt target gene that is over-expressed in HCC, and also a key regulator of cell division and inhibitor of apoptosis that has been demonstrated to be involved in tumor chemoresistance [42]. Additionally, we found that sFZD7 was able to decrease the levels of phospho-AKT 
A

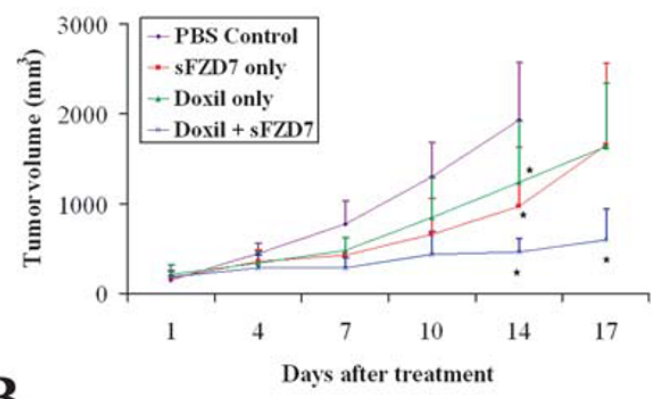

B
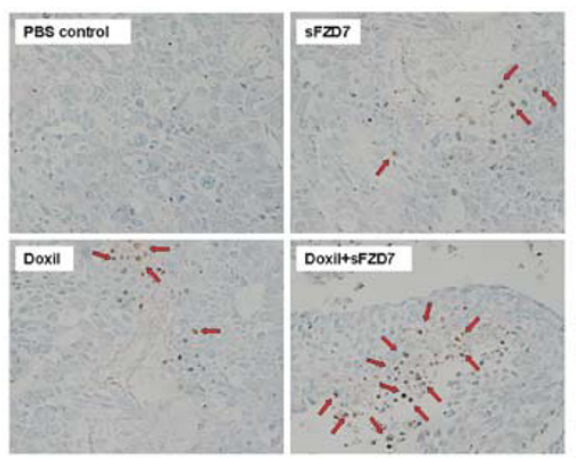

C

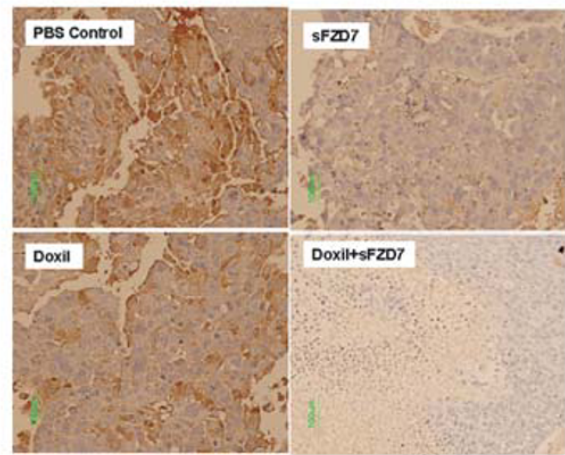

D

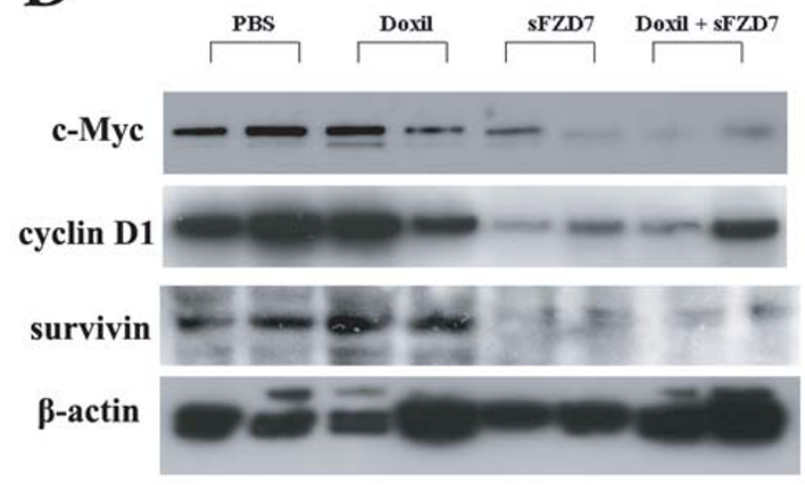

$\mathbf{E}$

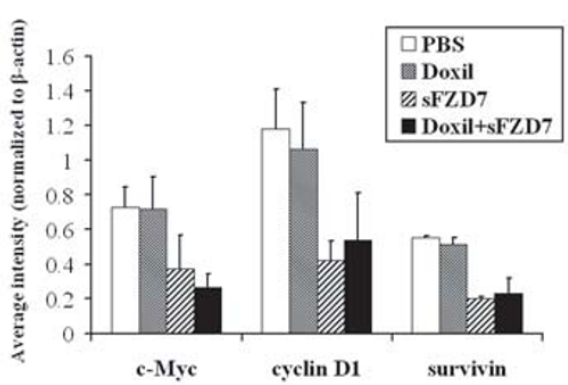

Figure 5 sFZD7 sensitizes HCC cells to the anti-proliferative effect of doxorubicin in vivo. (A). Combination of sFZD7 and Doxil enhanced xenograft growth inhibition in vivo. Mice bearing Huh7-tumor xenografts were intratumorally injected weekly with PBS control; sFZD7 only (12.5 mg/kg); Doxil only (2.5 mg/kg); or sFZD7 (12.5 mg/kg) combined with Doxil ( $2.5 \mathrm{mg} / \mathrm{kg})$ ( $\mathrm{n}=5$ in each treatment group). Tumor size was measured with digital calipers every three days. Significant differences in the tumor volumes between all treatment groups and the PBS control were observed after 14 days of treatment ( $\left.{ }^{*} P<0.05\right)$. Additionally, the sFZD7 plus Doxil combination group showed significant differences in tumor volumes compared with sFZD7 only or Doxil only groups after 17 days of treatment $\left({ }^{*} \mathrm{P}<0.05\right)$. (B). TUNEL staining of xenograft specimens removed from PBS control and all treatment groups (200 × magnification). Red arrows indicate some positively stained, apoptotic cells. (C). Representative cyclin D1 immunostaining of xenograft specimens removed from PBS control and all treatment groups are shown (200 $\times$ magnification). (D). Protein levels of c-Myc, cyclin D1, survivin, and $\beta$-actin (loading control) in tumor xenografts from two mice in each group were determined by Western blotting using specific antibodies. (E). The expression levels of c-Myc, cyclin D1, survivin were determined by analyzing Western blots with the ImageJ software, and normalizing their signal intensities to $\beta$-actin.

induced by doxorubicin alone. This concurs with a recent report by Ohigashi et al, who showed that inhibition of Wnt signaling by the Wnt inhibitory factor-1 down-regulated the AKT pathway, leading to enhanced chemosensitivity in PTEN-null prostate cancer cells [43]. Activation of the AKT pathway has been reported to be involved in the activation of $\mathrm{Wnt} / \beta$-catenin signaling pathway [29] and implicated in the development of acquired drug resistance [44]. Thus, we propose that sFZD7 might decrease survivin expression and inhibit the activation of AKT pathway, thereby contributing towards doxorubicin sensitization in HCC cells. 
Additionally, our results allude to complicated crosstalks among critical pathways (Wnt, AKT, ERK) that are involved in HCC. An increase in phosphorylation of ERK1/2 was previously observed in HCC cells treated with doxorubicin, as early as $30 \mathrm{~min}$ and up to $24 \mathrm{~h}$ after treatment, while total ERK levels were unchanged [45]. Earlier studies in other cell types concur with the ability of the doxorubicin and other DNA-damaging agents (such as etoposide) to induce ERK activation [46-49]. Activation of ERK in response to DNA damage might occur via p53-dependent or p53-independent (ATM-dependent) pathways, which then act cooperatively in enhancing cell cycle arrest and apoptosis [48-51]. In our study, sFZD7 further increased the ERK activation induced by doxorubicin in both HepG2 (wildtype p53) and Huh7 (mutant p53) cells, and may enhance sensitivity to doxorubicin by increasing cell cycle arrest and/or apoptosis.

\section{Conclusion}

Given the emerging interest in peptide-based cancer therapeutics, and recent advances in improving peptide stability and delivery $[52,53]$, we propose that the sFZD7 peptide is a feasible therapeutic agent that can be used to specifically abolish the functional activity of FZD7 in HCC. It has potential wide applicability in the treatment of HCC, especially when used in combination with agents targeting other components of the Wnt/ $\beta$-catenin signaling pathway, or with standard chemotherapeutic agents to increase drug sensitivity by modulating the activities of essential pathways in HCC. Further clinical translation of the sFZD7 peptide will require optimization of the peptide size and physicochemical properties to achieve desirable bioavailability [54].

\section{Materials and methods}

\section{Cell lines and primary cultures of hepatocytes}

Human hepatoma cell lines (Huh7, HepG2, Hep40) were maintained in Dulbecco's Modified Eagle's Medium (DMEM) supplemented with $10 \%$ fetal bovine serum (FBS), $100 \mu \mathrm{g} / \mathrm{mL}$ penicillin and $100 \mu \mathrm{g} / \mathrm{mL}$ streptomycin. All media and supplements were from Invitrogen (Carlsbad, CA). Cells were maintained at $37^{\circ}$ $\mathrm{C}$ in a humidified atmosphere with $5 \% \mathrm{CO}_{2}$.

Cryopreserved human hepatocytes, collagen-coated 96well plates, CHRM Thawing Medium, Cell Plating Medium, and Cell Maintenance Medium were received from CellzDirect/Invitrogen (Durham, NC). Characteristics of the hepatocytes and the plating method are as described previously [55].

\section{Plasmids}

Human Wnt3 cDNA clone pUSEamp-Wnt3 (HA-Wnt3) and the empty vector pUSEamp were from Millipore
(Billerica, MA). pCMV6-XL5-FZD7 and the empty vector pCMV-XL5 were from OriGene Technologies (Rockville, MD). TCF/Luc reporter constructs, pTOPFLASH (wild type) and pFOPFLASH (mutant), were from B Vogelstein (John Hopkins Oncology Center, Baltimore, MD, USA). The pet28A-sFZD7 was constructed by cloning the PCR-amplified product of the sFZD7 coding region into the BamHI and HindIII sites of vector pet28A (Merck Biosciences, Darmstadt, Germany). sFZD7 fragment was amplified using template containing full length FZD7 plasmid with the following primers: upstream (5'-TTTGGATCCTGCCAGCCCATCTCCAT3'), and downstream (5'-TTTAAGCTTCACCGGGTGCGGGCGAAGCGCCTCT-3'). The PCR reaction was performed in a GeneAmp PCR system 2700 (Applied Biosystems, Foster City, CA) under the following conditions: heat activation of the polymerase for $5 \mathrm{~min}$ at $94^{\circ} \mathrm{C}$, followed by 30 cycles of $95^{\circ} \mathrm{C}$ for $30 \mathrm{sec}$, $58^{\circ} \mathrm{C}$ for $30 \mathrm{sec}$, and $72^{\circ} \mathrm{C}$ for $45 \mathrm{sec}$; with a final extension at $72^{\circ} \mathrm{C}$ for $10 \mathrm{~min}$.

\section{Expression and purification of sFZD7}

Recombinant His-sFZD7 peptide was produced in E. coli (strain BL21, DE3) with IPTG induction, and purified from the insoluble fraction of the bacterial lysate with Ni-NTA (Qiagen, Carpinteria, CA) following the manufacturer's instructions. Elution was done with $8 \mathrm{M}$ urea elution buffer ( $\mathrm{pH}$ 4.0). Eluted His-sFZD7 fusion protein was dialyzed against phosphate-buffered saline (PBS) with a stepwise increasing $\mathrm{pH}$ gradient $(\mathrm{pH} 4.0$ to $\mathrm{pH}$ 7.4) at $4^{\circ} \mathrm{C}$. The concentration of final His-sFZD7 fusion peptide was determined by BCA protein assay (PIERCE, Rockford, IL) and purification was confirmed by SDSPAGE and immunoblotting using HRP-labeled anti-His tag antibody (1:1000, Abcam, Cambridge, MA).

\section{Pull down assay}

Huh7 cells $\left(5 \times 10^{6}\right)$ were lysed in RIPA buffer and the crude lysate was clarified by centrifugation at $12,000 \times \mathrm{g}$ for $5 \mathrm{~min}$. Recombinant His-sFZD7 peptide $(100 \mu \mathrm{g})$ was mixed with $15 \mu \mathrm{l} \mathrm{Ni-NTA}$ agarose beads (Qiagen, Carpinteria, CA) in binding buffer $\left(50 \mathrm{mM} \mathrm{NaH}{ }_{2} \mathrm{PO}_{4}\right.$, $300 \mathrm{mM} \mathrm{NaCl}, 10 \mathrm{mM}$ imidazole, $\mathrm{pH}$ 8.0) and incubated for $1 \mathrm{~h}$ with gentle rotation, and then washed with wash buffer $\left(50 \mathrm{mM} \mathrm{NaH} \mathrm{PO}_{4}, 300 \mathrm{mM} \mathrm{NaCl}\right.$, $40 \mathrm{mM}$ imidazole, $\mathrm{pH}$ 8.0). The Ni-NTA agarose with recombinant His-sFZD7 peptide was mixed with Huh7 cell lysate; mock agarose was separately mixed with Huh7 cell lysate. Imidazole was added to the mixtures at a final concentration of $40 \mathrm{mM}$, and incubated overnight with gentle rotation in $4^{\circ} \mathrm{C}$. After centrifugation at $400 \times$ g for $2 \mathrm{~min}$ at $4^{\circ} \mathrm{C}$, supernatants were discarded and the agarose mixtures were washed with binding buffer three times for $5 \mathrm{~min}$ each. The agarose mixtures 
with the protein complex were then eluted with elution buffer $\left(50 \mathrm{mM} \mathrm{NaH}_{2} \mathrm{PO}_{4}, 300 \mathrm{mM} \mathrm{NaCl}, 250 \mathrm{mM}\right.$ imidazole, $\mathrm{pH}$ 8.0) and the supernatants were resolved on SDS-PAGE. Western blots were done using the rabbit anti-Wnt3 (1:1000, Abcam, Cambridge, MA), and antiHis tag (1:1000, Abcam, Cambridge, MA) antibodies.

\section{Luciferase reporter gene assay}

Huh7 cells (at 50\% confluency) were transfected with $0.2 \mu \mathrm{g}$ of HA-Wnt3 or empty vector and $0.2 \mu \mathrm{g}$ of pCMV6-XL5-FZD7 or the empty vector, along with $0.3 \mu \mathrm{g}$ of $\mathrm{pTOPFLASH}$ or pFOPFLASH reporter plasmids and $0.1 \mu \mathrm{g}$ of $\beta$-gal to normalize for transfection efficiency. The amount of DNA in each transfection reaction was kept constant by adding an appropriate amount of the empty vector. Transfection was performed using Lipofectamine 2000 (Invitrogen, Carlsbad, CA) according to the manufacturer's instructions. After $4 \mathrm{~h}$, media containing transfection reagent were replaced with new culture media with or without sFZD7 $(2 \mu \mathrm{g} / \mathrm{ml})$. After $48 \mathrm{~h}$, cells were lysed in $100 \mu \mathrm{l}$ of lysis buffer, and $20 \mu \mathrm{l}$ aliquots were assayed using the Promega Luciferase assay system, and the Promega $\beta$-gal assay system. Relative light units (RLU) were measured and normalized for transfection efficiency using $\beta$-gal activity. Final RLU representing Tcf4 transcriptional activity were calculated by subtracting normalized levels obtained with pFOPFLASH from those obtained with pTOPFLASH.

\section{Protein extracts and immunoblotting}

Huh7 and HepG2 cells were seeded at 50\% confluency in 6-well plates and incubated at $37^{\circ} \mathrm{C}$ overnight. Cells were then treated with PBS, or with purified sFZD7 at desired concentrations $(2,10$, or $20 \mu \mathrm{g} / \mathrm{ml})$ for $48 \mathrm{~h}$. Cell monolayers were washed twice with PBS and then lysed in the RIPA extraction buffer. For nuclear $\beta$-catenin immunodetection, nuclear extracts were prepared with a NE-PER Nuclear and Cytoplasmic Extraction Kit (Pierce, Rockford, IL). Equal amounts of protein $(20 \mu \mathrm{g})$ were resolved by SDS-PAGE and Western blots were performed by using the primary antibodies to c-Myc (1:500, Cat. No. 551101, BD Pharmingen, San Diego, CA), cyclin D1 (1:1000, Cat. No. ab6152, Abcam, Cambridge, MA), survivin (1:1000, Cat. No. NB500-201H, Novas Biologicals, Littleton, CO), $\beta$-catenin (1:500; Cat. No. SC-7963, Santa Cruz Biotechnology Inc., Santa Cruz, CA), HRP-Histone H3 (1:10000, Cat. No. Ab21054, Abcam, Cambridge, MA) and HRP- $\beta$ actin (1:10000, Cat. No. A3854, Sigma-Aldrich, MO). Secondary antibodies (anti-mouse, Cat. No. SC-2005 and anti-rabbit, Cat. No. SC-2004) conjugated with horseradish peroxidase were from Santa Cruz Biotechnology, Inc. (Santa Cruz, CA).

For sFZD7 and doxorubicin combination treatment, Huh7 and HepG2 cells were treated with PBS, purified
sFZD7 alone $(10 \mu \mathrm{g} / \mathrm{ml}$ for $48 \mathrm{~h})$, doxorubicin alone $(2.5 \mu \mathrm{M}$ for $6 \mathrm{~h})$, or combination of sFZD7 and doxorubicin $(10 \mu \mathrm{g} / \mathrm{ml}$ of sFZD7 for $48 \mathrm{~h}$, followed by addition of $2.5 \mu \mathrm{M}$ doxorubicin for $6 \mathrm{~h}$ ). Cell monolayers were then lysed in the RIPA extraction buffer. Equal amounts of total cell protein $(20 \mu \mathrm{g})$ were resolved by SDS-PAGE and Western blots were performed by using the primary antibodies to ERK1/2 (1:1000, Cat. No. 9102, Cell Signaling Technology Inc., Danvers, MA), p-ERK1/2 (1:1000, Cat. No. 4370, Cell Signaling Technology Inc., Danvers, MA), AKT (1:1000, Cat. No. 9272, Cell Signaling Technology Inc., Danvers, MA), p-AKT (1:1000, Cat. No. 4058s, Cell Signaling Technology Inc., Danvers, MA).

\section{Quantitative real-time PCR assay}

Total RNA was extracted from hepatoma cells and hepatocytes by using the RNeasy mini kit (Qiagen, Valencia, CA) following the manufacturer's instructions. Concentration and purity of extracted RNA were determined by optical density measurement at 260 and $280 \mathrm{~nm}$. All real-time PCR reagents were from Applied Biosystems (Foster city, CA). Briefly, first-strand cDNA was generated by random primers using Taqman Reverse Transcriptional Reagent, and real-time PCR was performed by using Taqman Gene Expression Assay (Human FZD7 assay ID: Hs00275833_s1; Human Wnt3 assay ID: Hs00229135_m1) and Universal PCR Master Reagent in a Stratagene Mx3000P Q-PCR system (Stratagene, La Jolla, CA). These reactions were incubated at $95^{\circ} \mathrm{C}$ for $10 \mathrm{~min}$, followed by 40 cycles at $95^{\circ} \mathrm{C}$ for $15 \mathrm{sec}$, and $60^{\circ} \mathrm{C}$ for $1 \mathrm{~min}$. The expression level of FZD7 was measured in terms of threshold cycle value using Stratagene MxPro software and normalized to the internal control, human 18s rRNA (Part No. 4333760F).

\section{Cell viability assay}

Hepatoma cells were seeded in 96 -well plates at $3 \times 10^{3}$ cells/well, and normal hepatocytes seeded at $3 \times 10^{4}$ cells/well, and incubated overnight at $37^{\circ} \mathrm{C}$ prior to addition of sFZD7 at desired final concentrations (range from $1.25-20 \mu \mathrm{g} / \mathrm{ml}$ ). Cells were further incubated for 72 $\mathrm{h}$ before cell viability was assessed using CellTiter-Glo Luminescent Cell Viability Assay (Promega, Madison, WI) according to the manufacturer's instructions. Luciferase activity was measured on a luminometer (Berthold LB-96V) and values were normalized to the ATP activity and compared with the PBS control value, which was set at 100 . Three independent experiments were done, each in triplicates.

\section{Cell proliferation assay}

Hepatoma cells were seeded in 96 -well plates at $3 \times 10^{3}$ cells/well, maintained overnight at $37^{\circ} \mathrm{C}$, and incubated 
with doxorubicin (at various concentrations, ranging from $0-100 \mu \mathrm{M})$ with or without sFZD7 $(2 \mu \mathrm{g} / \mathrm{ml})$. After $72 \mathrm{~h}$ incubation, cell proliferation was monitored by using CellTiter $96^{\mathbb{B}}$ AQueous One Solution Cell Proliferation Assay (Promega, Madison, WI) according to the manufacturer's instructions. Optical density (OD) at $490 \mathrm{~nm}$ was read using a microplate reader (BioTek Instruments, Inc., Winooski, VT). The 50\% inhibitory concentrations $\left(\mathrm{IC}_{50} \mathrm{~s}\right)$ were calculated as an estimate of the anti-proliferative effects of doxorubicin alone or in combination with sFZD7.

\section{Xenografts in nude mice}

Animal experiments were approved by the Administrative Panel on Laboratory Animal Care at Stanford University. Nude mice (ATHYMIC NU/NU; Harlan Sprague-Dawley, Indianapolis, IN) at age 4-6 weeks (body weight of 18 to $25 \mathrm{~g}$ ) were used. Mice were injected subcutaneously at the dorsal region with $5 \times$ $10^{6}$ viable Huh7 cells. After two weeks, when tumors reached approximately $0.4-0.5 \mathrm{~cm}$ in diameter, mice were randomized into four groups $(\mathrm{n}=5$ each) to be intratumorally injected with (1). PBS control $(100 \mu \mathrm{l}$, once weekly); (2). purified sFZD7 (dose:12.5 mg/kg; volume: $100 \mu \mathrm{l}$; once weekly); (3). Doxil (dose: $2.5 \mathrm{mg}$ / kg; volume: $100 \mu \mathrm{l}$; once weekly); or (4). sFZD7 (dose: $12.5 \mathrm{mg} / \mathrm{kg}$; volume: $100 \mu \mathrm{l}$; once weekly) plus Doxil (dose: $2.5 \mathrm{mg} / \mathrm{kg}$; volume: $100 \mu \mathrm{l}$; once weekly). Doxil is a liposomal formulation of doxorubicin for intravenous use. Intratumor administration was chosen to mimic the clinically used treatment method of chemoembolization, which delivers cytotoxic drugs directly to the HCC tumor for greater efficacy and reduced toxicity. Tumor size was measured with digital calipers every three days and was calculated using the formula $\pi / 6 \times$ larger diameter $\times[\text { smaller diameter }]^{2}$. Mice in the PBS group were sacrificed after 14 days, whereas mice in other treatment groups were sacrificed after 17 days of treatment. Tumor tissues were harvested for immunohistochemistry as described below, and for TUNEL staining using the ApopTag Peroxidase in Situ Oligo Ligation Apoptosis Detection Kit (Chemicon International, Temecula, CA) according to the manufacturer's protocol. We assessed the percentage of cells that stained positively with brown nuclei in five randomly selected areas of 100 cells per area. Western blot was used to quantify the protein levels of c-Myc, cyclin D1, or survivin in tumor xenografts of two mice in each group. The antibodies used were: HRP-conjugated anti c-Myc (1:1000, Cat. No. ab62928, Abcam, Cambridge, MA), biotin-conjugated anti-cyclin D1 (1:1000, Cat. No. MS210-B0, Thermo Scientific, Fremont, CA), HRP-conjugated anti-survivin $(1: 1000$, Cat. No. NB500-201H, Novas Biologicals, Littleton, CO), HRP-conjugated $\beta$-actin (1:10000, Cat. No. A3854, Sigma-Aldrich, St. Louis, MO), and secondary antibodies (anti-biotin) conjugated with HRP (1:1000, Cat. No. Ab19221-1, Abcam, Cambridge, MA). Western blots were analyzed by ImageJ software, and signal intensities normalized to $\beta$-actin.

\section{Immunohistochemistry analysis}

Immunoperoxidase staining of tumor xenografts was performed on formalin-fixed 4- $\mu \mathrm{m}$ tissue section. Briefly, sections were incubated with monoclonal mouse antihuman c-Myc (1:200, Cat. No. 551101, BD Pharmingen, San Diego, CA), cyclin D1 (1:250, Cat. No. ab6152, Abcam, Cambridge, MA), or survivin (1:500, Cat. No. NB500-201H, Novas Biologicals, Littleton, CO) and then washed with PBS. Subsequent procedures were performed using Dakocytomation Envision System-HRP mouse system (Dako, Carpinteria, CA) according to the manufacturer's protocol.

\section{Statistical analysis}

Statistical significance was determined by the independent-sample T-test using the computer SPSS software (version 10.0; SPSS, Chicago, IL). P values less than 0.05 were considered statistically significant.

\section{Abbreviations}

FZD7: Frizzled-7; HCC: Hepatocellular carcinoma; Pl: propidium iodide; Tcf4: T-cell factor 4; TUNEL: Terminal dUTP nick-end labeling

\section{Acknowledgements}

This work is supported by grants to the Asian Liver Center at Stanford University from the C. J. Huang and H. M. Lui Foundations.

\section{Author details}

${ }^{1}$ Asian Liver Center, Department of Surgery, 1201 Welch Road, Stanford University School of Medicine, Stanford, CA 94305, USA. ${ }^{2}$ CellzDirect/ Invitrogen, 4301 Emperor Blvd, Durham, NC 27703, USA.

\section{Authors' contributions}

WW contributed to the major part of experimental work, interpreted the results, performed the statistics and drafted the manuscript. MC conceived the study, participated in its design and data analysis, and contributed with scientific discussion and manuscript preparation. SG contributed the normal hepatocytes and provided training and advice on culturing the hepatocytes. SKS is the principal investigator, responsible for conception of the project, designing the experiments, and approving the final manuscript. All authors read and approved the final manuscript.

\section{Competing interests}

The authors declare that they have no competing interests.

Received: 14 September 2010 Accepted: 11 February 2011 Published: 11 February 2011

\section{References}

1. Lee HC, Kim M, Wands JR: Wnt/Frizzled signaling in hepatocellular carcinoma. Front Biosci 2006, 11:1901-1915.

2. Takigawa $Y$, Brown AM: Wnt signaling in liver cancer. Curr Drug Targets 2008, 9:1013-1024

3. Devereux TR, Stern MC, Flake GP, Yu MC, Zhang ZQ, London SJ, Taylor JA: CTNNB1 mutations and beta-catenin protein accumulation in human 
hepatocellular carcinomas associated with high exposure to aflatoxin B1. Mol Carcinog 2001, 31:68-73.

4. Wong CM, Fan ST, Ng IO: beta-Catenin mutation and overexpression in hepatocellular carcinoma: clinicopathologic and prognostic significance. Cancer 2001, 92:136-145.

5. Cui J, Zhou X, Liu Y, Tang Z, Romeih M: Wnt signaling in hepatocellular carcinoma: analysis of mutation and expression of beta-catenin, T-cell factor-4 and glycogen synthase kinase 3-beta genes. J Gastroenterol Hepatol 2003, 18:280-287.

6. Hsu HC, Jeng YM, Mao TL, Chu JS, Lai PL, Peng SY: Beta-catenin mutations are associated with a subset of low-stage hepatocellular carcinoma negative for hepatitis B virus and with favorable prognosis. Am J Pathol 2000, 157:763-770.

7. Prange W, Breuhahn K, Fischer F, Zilkens C, Pietsch T, Petmecky K, Eilers R, Dienes HP, Schirmacher P: Beta-catenin accumulation in the progression of human hepatocarcinogenesis correlates with loss of E-cadherin and accumulation of $\mathrm{p} 53$, but not with expression of conventional WNT-1 target genes. J Pathol 2003, 201:250-259.

8. Satoh S, Daigo Y, Furukawa Y, Kato T, Miwa N, Nishiwaki T, Kawasoe T, Ishiguro H, Fujita M, Tokino T, et al: AXIN1 mutations in hepatocellular carcinomas, and growth suppression in cancer cells by virus-mediated transfer of AXIN1. Nat Genet 2000, 24:245-250.

9. Taniguchi K, Roberts LR, Aderca IN, Dong X, Qian C, Murphy LM, Nagorney DM, Burgart LJ, Roche PC, Smith DI, et al: Mutational spectrum of beta-catenin, AXIN1, and AXIN2 in hepatocellular carcinomas and hepatoblastomas. Oncogene 2002, 21:4863-4871.

10. Zucman-Rossi J, Benhamouche S, Godard C, Boyault S, Grimber G, Balabaud C, Cunha AS, Bioulac-Sage P, Perret C: Differential effects of inactivated Axin1 and activated beta-catenin mutations in human hepatocellular carcinomas. Oncogene 2007, 26:774-780.

11. Shih YL, Hsieh CB, Lai HC, Yan MD, Hsieh TY, Chao YC, Lin YW: SFRP1 suppressed hepatoma cells growth through Wnt canonical signaling pathway. Int J Cancer 2007, 121:1028-1035.

12. Kim M, Lee HC, Tsedensodnom O, Hartley R, Lim YS, Yu E, Merle P, Wands JR: Functional interaction between Wnt3 and Frizzled-7 leads to activation of the Wnt/beta-catenin signaling pathway in hepatocellular carcinoma cells. J Hepatol 2008, 48:780-791.

13. Merle P, de la Monte S, Kim M, Herrmann M, Tanaka S, Von Dem Bussche A, Kew MC, Trepo C, Wands JR: Functional consequences of frizzled-7 receptor overexpression in human hepatocellular carcinoma. Gastroenterology 2004, 127:1110-1122.

14. Bengochea A, de Souza MM, Lefrancois L, Le Roux E, Galy O, Chemin I, Kim M, Wands JR, Trepo C, Hainaut P, et al: Common dysregulation of $\mathrm{Wnt} /$ Frizzled receptor elements in human hepatocellular carcinoma. $\mathrm{Br} J$ Cancer 2008, 99:143-150

15. Wang HY, Liu T, Malbon CC: Structure-function analysis of Frizzleds. Cell Signal 2006, 18:934-941.

16. Merle P, Kim M, Herrmann M, Gupte A, Lefrancois L, Califano S, Trepo C, Tanaka S, Vitvitski L, de la Monte S, Wands JR: Oncogenic role of the frizzled-7/beta-catenin pathway in hepatocellular carcinoma. $J$ Hepatol 2005, 43:854-862.

17. Kawano Y, Kypta R: Secreted antagonists of the Wnt signalling pathway. J Cell Sci 2003, 116:2627-2634.

18. He X, Saint-Jeannet JP, Wang Y, Nathans J, Dawid I, Varmus H: A member of the Frizzled protein family mediating axis induction by Wnt-5A. Science 1997, 275:1652-1654.

19. Vincan E, Darcy PK, Smyth MJ, Thompson EW, Thomas RJ, Phillips WA, Ramsay RG: Frizzled-7 receptor ectodomain expression in a colon cancer cell line induces morphological change and attenuates tumor growth. Differentiation 2005, 73:142-153

20. Ueno K, Hiura M, Suehiro Y, Hazama S, Hirata H, Oka M, Imai K, Dahiya R, Hinoda Y: Frizzled-7 as a potential therapeutic target in colorectal cancer. Neoplasia 2008, 10:697-705.

21. de La Coste A, Romagnolo B, Billuart P, Renard CA, Buendia MA, Soubrane O, Fabre M, Chelly J, Beldjord C, Kahn A, Perret C: Somatic mutations of the beta-catenin gene are frequent in mouse and human hepatocellular carcinomas. Proc Natl Acad Sci USA 1998, 95:8847-8851.

22. Ito T, Shiraki K, Sugimoto K, Yamanaka T, Fujikawa K, Ito M, Takase $K$, Moriyama M, Kawano H, Hayashida M, et al: Survivin promotes cell proliferation in human hepatocellular carcinoma. Hepatology 2000, 31:1080-1085.
23. Liu YC, Chen CJ, Wu HS, Chan DC, Yu JC, Yang AH, Cheng YL, Lee SC, Harn HJ: Telomerase and c-myc expression in hepatocellular carcinomas. Eur J Surg Oncol 2004, 30:384-390.

24. Masaki T, Shiratori $Y$, Rengifo $W$, Igarashi $K$, Yamagata M, Kurokohchi $K$ Uchida N, Miyauchi Y, Yoshiji H, Watanabe S, et al: Cyclins and cyclindependent kinases: comparative study of hepatocellular carcinoma versus cirrhosis. Hepatology 2003, 37:534-543.

25. Bourguignon LY, Xia W, Wong G: Hyaluronan-mediated CD44 interaction with p300 and SIRT1 regulates beta-catenin signaling and NFkappaBspecific transcription activity leading to MDR1 and Bcl-xL gene expression and chemoresistance in breast tumor cells. J Biol Chem 2009, 284:2657-2671.

26. Flahaut M, Meier R, Coulon A, Nardou KA, Niggli FK, Martinet $D$, Beckmann JS, Joseph JM, Muhlethaler-Mottet A, Gross N: The Wnt receptor FZD1 mediates chemoresistance in neuroblastoma through activation of the Wnt/beta-catenin pathway. Oncogene 2009, 28:2245-2256.

27. Kobune M, Chiba H, Kato J, Kato K, Nakamura K, Kawano Y, Takada K, Takimoto R, Takayama T, Hamada H, Niitsu Y: Wnt3/RhoA/ROCK signaling pathway is involved in adhesion-mediated drug resistance of multiple myeloma in an autocrine mechanism. Mol Cancer Ther 2007, 6:1774-1784.

28. Noda T, Nagano H, Takemasa I, Yoshioka S, Murakami M, Wada H, Kobayashi S, Marubashi S, Takeda Y, Dono K, et al: Activation of Wnt/betacatenin signalling pathway induces chemoresistance to interferon-alpha/ 5-fluorouracil combination therapy for hepatocellular carcinoma. $\mathrm{Br} J$ Cancer 2009, 100:1647-1658.

29. Almeida M, Han L, Bellido T, Manolagas SC, Kousteni S: Wnt proteins prevent apoptosis of both uncommitted osteoblast progenitors and differentiated osteoblasts by beta-catenin-dependent and -independent signaling cascades involving SrC/ERK and phosphatidylinositol 3-kinase/ AKT. J Biol Chem 2005, 280:41342-41351

30. Llovet JM, Bruix J: Molecular targeted therapies in hepatocellular carcinoma. Hepatology 2008, 48:1312-1327.

31. Llovet JM, Ricci S, Mazzaferro V, Hilgard P, Gane E, Blanc JF, de Oliveira AC, Santoro A, Raoul JL, Forner A, et al: Sorafenib in advanced hepatocellular carcinoma. N Engl J Med 2008, 359:378-390.

32. Avila MA, Berasain C, Sangro B, Prieto J: New therapies for hepatocellular carcinoma. Oncogene 2006, 25:3866-3884.

33. Fujii N, You L, Xu Z, Uematsu K, Shan J, He B, Mikami I, Edmondson LR, Neale G, Zheng J, et al: An antagonist of dishevelled protein-protein interaction suppresses beta-catenin-dependent tumor cell growth. Cancer Res 2007, 67:573-579.

34. Zeng G, Apte U, Cieply B, Singh S, Monga SP: siRNA-mediated betacatenin knockdown in human hepatoma cells results in decreased growth and survival. Neoplasia 2007, 9:951-959.

35. Khan NI, Bradstock KF, Bendall L: Activation of Wnt/beta-catenin pathway mediates growth and survival in B-cell progenitor acute lymphoblastic leukaemia. Br J Haematol 2007, 138:338-348.

36. Kirikoshi $\mathrm{H}$, Sekihara $\mathrm{H}$, Katoh M: Up-regulation of Frizzled-7 (FZD7) in human gastric cancer. Int J Oncol 2001, 19:111-115.

37. Tanaka S, Akiyoshi T, Mori M, Wands JR, Sugimachi K: A novel frizzled gene identified in human esophageal carcinoma mediates APC/beta-catenin signals. Proc Natl Acad Sci USA 1998, 95:10164-10169.

38. Vincan E, Darcy PK, Farrelly CA, Faux MC, Brabletz T, Ramsay RG: Frizzled-7 dictates three-dimensional organization of colorectal cancer cell carcinoids. Oncogene 2007, 26:2340-2352.

39. Zeng ZY, Zhou YH, Zhang WL, Xiong W, Fan SQ, Li XL, Luo XM, Wu MH, Yang YX, Huang C, et al: Gene expression profiling of nasopharyngeal carcinoma reveals the abnormally regulated Wnt signaling pathway. Hum Pathol 2007, 38:120-133.

40. Hocevar BA, Mou F, Rennolds JL, Morris SM, Cooper JA, Howe PH: Regulation of the Wnt signaling pathway by disabled-2 (Dab2). Embo $J$ 2003, 22:3084-3094.

41. Spangenberg HC, Thimme R, Blum HE: Targeted therapy for hepatocellular carcinoma. Nat Rev Gastroenterol Hepatol 2009, 6:423-432.

42. Altieri DC: Survivin, cancer networks and pathway-directed drug discovery. Nat Rev Cancer 2008, 8:61-70.

43. Ohigashi T, Mizuno R, Nakashima J, Marumo K, Murai M: Inhibition of Wnt signaling downregulates Akt activity and induces chemosensitivity in PTEN-mutated prostate cancer cells. Prostate 2005, 62:61-68.

44. Wong KK, Engelman JA, Cantley LC: Targeting the PI3K signaling pathway in cancer. Curr Opin Genet Dev 20:87-90. 
45. Choi J, Yip-Schneider M, Albertin F, Wiesenauer C, Wang Y, Schmidt CM: The effect of doxorubicin on MEK-ERK signaling predicts its efficacy in HCC. J Surg Res 2008, 150:219-226.

46. Lee ER, Kim JY, Kang YJ, Ahn JY, Kim JH, Kim BW, Choi HY, Jeong MY, Cho SG: Interplay between PI3K/Akt and MAPK signaling pathways in DNA-damaging drug-induced apoptosis. Biochim Biophys Acta 2006, 1763:958-968.

47. Manov I, Bashenko Y, Eliaz-Wolkowicz A, Mizrahi M, Liran O, lancu TC: Highdose acetaminophen inhibits the lethal effect of doxorubicin in HepG2 cells: the role of P-glycoprotein and mitogen-activated protein kinase p44/42 pathway. J Pharmacol Exp Ther 2007, 322:1013-1022.

48. Persons DL, Yazlovitskaya EM, Pelling JC: Effect of extracellular signalregulated kinase on p53 accumulation in response to cisplatin. $J$ Biol Chem 2000, 275:35778-35785.

49. Tang D, Wu D, Hirao A, Lahti JM, Liu L, Mazza B, Kidd VJ, Mak TW, Ingram AJ: ERK activation mediates cell cycle arrest and apoptosis after DNA damage independently of p53. J Biol Chem 2002, 277:12710-12717.

50. Lee SW, Fang L, Igarashi M, Ouchi T, Lu KP, Aaronson SA: Sustained activation of Ras/Raf/mitogen-activated protein kinase cascade by the tumor suppressor p53. Proc Natl Acad Sci USA 2000, 97:8302-8305.

51. Wei F, Xie Y, Tao L, Tang D: Both ERK1 and ERK2 kinases promote G2/M arrest in etoposide-treated MCF7 cells by facilitating ATM activation. Cell Signal 22:1783-1789.

52. Borghouts C, Kunz C, Groner B: Current strategies for the development of peptide-based anti-cancer therapeutics. J Pept Sci 2005, 11:713-726.

53. Sehgal A: Recent developments in peptide-based cancer therapeutics. Curr Opin Drug Discov Devel 2002, 5:245-250.

54. Smith HJ, Williams H: Smith and Williams' introduction to the principles of drug design and action. Boca Raton: Taylor \& Francis; 42006.

55. Wei W, Chua MS, Grepper S, So S: Small molecule antagonists of Tcf4/ beta-catenin complex inhibit the growth of HCC cells in vitro and in vivo. Int J Cancer 2010, 126(10):2426-36.

doi:10.1186/1476-4598-10-16

Cite this article as: Wei et al:: Soluble Frizzled-7 receptor inhibits Wnt signaling and sensitizes hepatocellular carcinoma cells towards doxorubicin. Molecular Cancer 2011 10:16.

\section{Submit your next manuscript to BioMed Central and take full advantage of:}

- Convenient online submission

- Thorough peer review

- No space constraints or color figure charges

- Immediate publication on acceptance

- Inclusion in PubMed, CAS, Scopus and Google Scholar

- Research which is freely available for redistribution

Submit your manuscript at www.biomedcentral.com/submit 